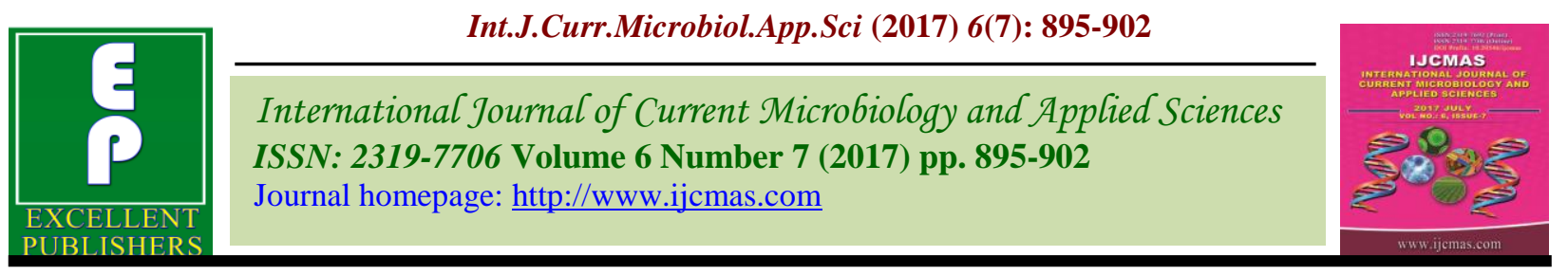

Original Research Article

https://doi.org/10.20546/ijcmas.2017.607.110

\title{
Effect of 14-Year Long Term Fertilizer Management on Soil Organic Carbon Stock, Carbon Sequestration Rate and Nutrient Balances in Vertisols
}

\author{
Challa Venu Reddy*, Laxmi Kashyap and Alok Tiwari \\ Indira Gandi Krishi Vishwa Vidhyalaya, Raipur, Chattishgarh, India \\ *Corresponding author
}

\begin{tabular}{|c|c|}
\hline & A B S T R A C T \\
\hline Keywords & \multirow{4}{*}{$\begin{array}{l}\text { Soil organic carbon (SOC) sequestration is important for improving soil fertility of } \\
\text { cropland and for the mitigation of greenhouse gas emissions to the atmosphere. The } \\
\text { efficiency of SOC sequestration depends on the quantity and quality of the organic matter, } \\
\text { soil type, and climate. Little is known about the SOC sequestration efficiency of organic } \\
\text { amendments in Vertisols. Thus, we conducted the research based on } 14 \text { years (1999-2013) } \\
\text { of long-term fertilization experiment with a no fertilizer control, } 50 \% \text { NPK, } 100 \% \text { NPK, } \\
150 \% \text { NPK, 100\% NPK+Zn, 100\% NP, 100\% N, 100\% NPK+FYM, 50\% NPK+BGA and } \\
50 \% \text { NPK+GM. Mean SOC sequestration rate was } 0.812 \text { ton/ha/yr in } 150 \% \text { NPK } \\
\text { treatment and } 0.206,0.13,-0.662,-0.821,-1.025,-1.082,-1.724,-2.817 \text { and }-3.302 \mathrm{t} / \mathrm{ha} / \mathrm{yr} \\
\text { in 100\% NPK, 100\% NPK+FYM, 50\% NPK+GM, 50\% NPK, 100\% NPK+Zn, 50\% } \\
\text { NPK+BGA, 100\% NP, 100\%N and Control respectively. The Change in Nutrient balances } \\
\text { higher values were recorded in inorganic treatments compare to the organic treatments due } \\
\text { to increasing rates of fertilizer application increased nutrient balance. }\end{array}$} \\
\hline $\begin{array}{l}\text { Soil organic } \\
\text { carbon, } \\
\text { SOC } \\
\text { sequestration, } \\
\text { Vertisols, } \\
\text { Nutrient balances. }\end{array}$ & \\
\hline Article Info & \\
\hline $\begin{array}{l}\text { Accepted: } \\
\text { 14 June } 2017 \\
\text { Available Online: } \\
\text { 10 July } 2017\end{array}$ & \\
\hline
\end{tabular}

\section{Introduction}

Fertilizers are usually applied to soil for increasing or maintaining crop yields to meet the increasing demand of food. Application of inorganic fertilizers results in higher soil organic matter (SOM) accumulation and biological activity due to increased plant biomass production and organic matter returns to soil in the form of decaying roots, litter and crop residues. Addition of SOM enhances soil organic carbon (SOC) content, which is an important indicator of soil quality and crop productivity (Lal, 2003). Sequestration of SOC is the key to reduce greenhouse gas emissions and lower the carbon footprint of farming (Jarecki and Lal, 2003). Fertilizer additions also affect the chemical composition of soil solution which can be responsible for dispersion/flocculation of clay particles and thus, affects the soil aggregation stability (Haynes and Naidu, 1998).

A traditional agricultural practice of applying nutrients was through organic manures such as green manures, farmyard manure (FYM). Organic manure applications improved soil physical properties through increased soil aggregation, decrease in the volume of micropores while increasing macropores, increased saturated hydraulic conductivity and water infiltration rate and improved soil water-holding capacity at both field capacity 
and wilting point. Organic manures and compost applications resulted in higher SOC content compared to same amount of inorganic fertilizers applications (Gregorich et al., 2001). Although, the accumulation of SOM through applied organic manures depends upon the rate of decomposition process. Significantly higher SOM content was found from depth $0-20 \mathrm{~cm}$ in winter wheat and summer maize rotation after 13 years of manure application along with NPK compared to non-treated control and only NPK treatment (Zhang et al., 2006). Several studies have reported that FYM plus inorganic $\mathrm{N}$ applications in irrigated systems resulted in reduced bulk density, higher SOC and hydraulic conductivity and improved soil structure and microbial communities (Bhattacharyya et al., 2007).

Soil management practices greatly affect the SOM and soil fertility. The SOM levels depend upon factors such as crop rotation, tillage methods, fertility management including use of inorganic fertilizers and organic manures and other components of cropping system. Continuous cultivation of crops has resulted in reduction in SOC and soil physical properties in general. Maintaining SOM concentration above the threshold level is critical for improving soil quality. A judicious combination of organic amendments and inorganic fertilizers is widely recognized strategy of integrated nutrient management (INM) to sustain agronomic productivity and improve soil fertility. Fertilizer applications and crop rotation can regulate $\mathrm{C}$ cycling dynamics and soil $\mathrm{C}$ storage through its effects on biological activity in soil and the amount and quality of residue returned to the soil. Long-term experiments can be more useful for studying the changes in soil properties and processes over time and for obtaining information on sustainability of agricultural systems for developing future strategies to maintain soil health. Therefore, the objectives of this study were to assess the effect of long-term (14 years) use of farmyard manure and inorganic fertilizers in Rice-wheat rotation on SOC, SOC stock, Nutrient balances and crop yields.

\section{Materials and Methods}

A field experiment was conducted on Vertisol of Research Farm, College of Agriculture, Indira Gandhi Krishi Vishwavidhyalaya, Raipur, Chhattisgarh. Raipur is situated at $21^{0}$ 4' North Latitude and $81^{\circ} 4^{\prime}$ East Longitude with the altitude of 293 meter above mean sea level.

The experimental soil (Vertisol) is fine montmorillonite, hyperthermic, udic chromustert, locally called as Kanhar and is identified as Arang II series. It is usually deep, heavy clayey (50 \%), dark brown to black in colour and neutral to slightly alkaline in reaction due to presence of lime concentrations. The soil was analyzed for its initial characteristics as per the methods mentioned below and some important physico-chemical properties of the soil are given in Table.1. Treatment details are $\mathrm{T}_{1}-$ Control, $\mathrm{T}_{2}-50 \%$ of the recommended optimum NPK dose, $\mathrm{T}_{3}-100 \%$ of the rec. optimum NPK dose, $\mathrm{T}_{4}-150 \%$ of the rec. optimum NPK dose, $\mathrm{T}_{5}-100 \%$ of the rec. optimum NPK + $\mathrm{ZnSO}_{4} @ 10 \mathrm{~kg} \mathrm{ha}^{-1}$ in kharif crop only, $\mathrm{T}_{6}-100 \% \mathrm{NP}$ of rec. optimum $\mathrm{N}$ and $\mathrm{P}$ dose, $\mathrm{T}_{7}-100 \% \mathrm{~N}$ of rec. optimum N dose, $\mathrm{T}_{8}-100 \% \mathrm{NPK}+\mathrm{FYM}(5 \mathrm{t}$ $\mathrm{ha}^{-1}$ in kharif crop only), $\mathrm{T}_{9}-50 \% \mathrm{NPK}+$ BGA $\left(10 \mathrm{~kg} \mathrm{ha}^{-1}\right.$ dry culture in kharif crop only), $\mathrm{T}_{10}-50 \% \mathrm{NPK}+\mathrm{GM}$ (sown in site and mixed in soil in kharif season only).

Soil samples were collected from 0-15 depth after wheat harvesting. Organic $\mathrm{C}$ was determined by the wet digestion method of Walkley and Black (1934). Analysis of variance (ANOVA) was carried out using the 
randomized block design method and Least Significance Difference (LSD) was calculated on soil data for treatment means at 5 per cent probability.

The soil organic carbon stock and Csequestration rate was calculated according to the following equation:

Soil organic carbon stock $(\mathrm{Kg} / \mathrm{ha})=\mathrm{D} \times \mathrm{OC}$ $(\%) \times \mathrm{BD} / 100$

Where D is depth of the soil in $\mathrm{cm}, \mathrm{OC}$ is soil organic carbon in percentage and $\mathrm{BD}$ is bulk density $\left(\mathrm{Mg} / \mathrm{m}^{3}\right)$.

C-sequestration rate $\left(\mathrm{kg} \mathrm{ha}^{-1} \mathrm{yr}^{-1}\right)=$ Final SOC (kg/ha) - initial SOC (kg/ha)/ Time (year)

\section{Nutrient balance calculation}

Nutrient balance calculations at field level are based on the difference between nutrient input and nutrient output. Essentially, it is necessary to keep nutrient inputs and outputs in balance to maintain soil fertility. Nutrient inputs were calculated for fertilizer and manure applications. Nutrient outputs were calculated for uptake by the removal of the harvested crop. Crop and soil nutrient determinations were made according to the analytical methods.

\section{Result and Discussion}

Soil organic carbon stock and carbon sequestration rate

Soil bulk density (BD) decreased in all fertilization treatments but not in the Control treatment (Table 5). The decrease was largest in the treatments receiving $100 \% \mathrm{NPK}+\mathrm{FYM}$, which suggests that long-term application of organic amendments significantly improved soil physical conditions. The Mean SOC stock over the 14 years of experimental period ranged from 9.43 to 13.55 ton $/$ ha. Higher values were recorded in $150 \%$ NPK $(13.55$ t/ha) followed by $100 \%$ NPK+FYM (12.87 $\mathrm{t} / \mathrm{ha})$ and the lower values were recorded in Control (9.43 t/ha) followed by 100\% N (9.93 t/ha) Table.5 and Fig.1. The mean SOC sequestration rate ranged from -3.302 t0 $0.812 \mathrm{t} / \mathrm{ha} /$ year in control to $150 \% \mathrm{NPK}$ treatment. The mean SOC sequestration rate followed the order: $150 \% \quad$ NPK $>100 \%$ $\mathrm{NPK}>100 \% ; \mathrm{NPK}+\mathrm{FYM}>50 \% ; \mathrm{NPK}+\mathrm{GM}>$ $50 \% ; \quad \mathrm{NPK}>100 \% \quad \mathrm{NPK}+\mathrm{Zn}>50 \%$ NPK+BGA $>100 \% \quad \mathrm{NP}>100 \% \mathrm{~N}>$ Control. These findings are consistant with a large body of evidence indicating that the long-term fertilizer and manure applications in SOC content of vertisols. The results were indicated that SOC sequestration rate changes were related to total ' $\mathrm{C}$ ' inputs. The relationship between SOC stock and Bulk density was presented in Fig.2. There was a significantly positive linear correlation between SOC stock and Bulk density $\left(\mathrm{R}^{2}=0.295\right)$.

Soil organic carbon (SOC) sequestration contributes to the mitigation of greenhouse gas emissions and to the improvement of soil fertility (Lal, 2004). Net SOC sequestration is the balance of organic $\mathrm{C}$ inputs into the soil (via crop residues, organic amendments in compost, animal manure, etc.) and organic $\mathrm{C}$ decomposition by soil microbes. SOC sequestration efficiency is commonly expressed by the relationship between annual $\mathrm{C}$ input and SOC accumulation rate, which is an indicator of soil $\mathrm{C}$ sequestration ability (McLauchlan, 2006). Therefore, information about the $\mathrm{C}$ sequestration efficiency is useful for seeking high efficiency management strategies of enhancing the SOC stock and soil fertility. Continuous cropping and integrated use of organic and inorganic fertilizers increased soil $\mathrm{C}$ sequestration and crop yields. Balanced application of NPK 
fertilizers with FYM was best option for higher crop yields in maize-wheat rotation (Brar, 2015).

\section{Change in nutrient balances}

\section{Change in nitrogen balance}

The Nitrogen balance in table 2 i.e. $\mathrm{N}$ uptake as measured by total harvest production (straw + grain) compared with Nitrogen fertilizer application was negative up to a high level of Nitrogen fertilization $150 \%$ NPK and $100 \%$ NPK + FYM was there a positive balance, remaining all treatments shown negative change. Similar results are obtained by Cermak and Smatanova (2012).

In this simplified form of balance, the amounts of nitrogen from atmospheric deposition and from biofixation were not taken into account. Had these contributions been included, uptake and input of $\mathrm{N}$ would probably have been fairly well balanced or slightly positive even at a medium level of $\mathrm{N}$ fertilization. When $\mathrm{N}$ is supplied in excess of that taken up by the crop, the higher the $\mathrm{N}$ application, the more $\mathrm{N}$ is going to be lost by leaching and in gaseous form.

\section{Change in phosphorus and potassium balance}

The higher change in ' $\mathrm{P}$ ' balance increased in $150 \%$ NPK followed by $100 \%$ NPK+FYM treatments. The Negative values are recorded in Control and $100 \% \mathrm{~N}$ treatments (Table.3). Phosphors uptake and input were already well-balanced at a low levels of phosphorus fertilization.

Table.1 Some important initial physico-chemical properties of the soil under study

\begin{tabular}{|c|c|c|}
\hline S.no & Properties & Value \\
\hline \multirow[t]{4}{*}{1.} & Mechanical composition & \\
\hline & Sand $(\%)$ & 20 \\
\hline & Silt (\%) & 34 \\
\hline & Clay $(\%)$ & 46 \\
\hline 2. & Texture & Clayey \\
\hline 3. & Bulk Density $\left(\mathrm{Mg} \mathrm{m}^{-3}\right)$ & 1.37 \\
\hline 4. & Hydraulic Conductivity $\left(\mathrm{mm} \mathrm{hr}^{-1}\right)$ & 4.8 \\
\hline 5. & Infiltration Rate $\left(\mathrm{mm} \mathrm{hr}^{-1}\right)$ & 5 \\
\hline 6. & Soil Classification & $\begin{array}{c}\text { Fine montmorillonite } \\
\text { hyperthermic, chromustert }\end{array}$ \\
\hline 7. & $\mathrm{pH}-(1: 2.5)$ & 7.7 \\
\hline 8. & $\mathrm{Ec}-\left(\mathrm{ds} \mathrm{\textrm {m } ^ { - 1 } )}\right.$ & 0.20 \\
\hline 9. & Organic Carbon $\left(\mathrm{g} \mathrm{Kg}^{-1}\right)$ & 6.2 \\
\hline 10. & $\mathrm{CEC}\left[\mathrm{c} \mathrm{mol}\left(\mathrm{p}^{+}\right) \mathrm{Kg}^{-1}\right]$ & 38.0 \\
\hline 11. & Available Nitrogen $\left(\mathrm{Kg} \mathrm{ha}^{-1}\right)$ & 236 \\
\hline 12. & Available Phosphorus $\left(\mathrm{Kg} \mathrm{ha}^{-1}\right)$ & 16.0 \\
\hline 13. & Available Potassium $\left(\mathrm{Kg} \mathrm{ha}^{-1}\right)$ & 474 \\
\hline 14. & DTPA extract Zn $\left(\mathrm{mg} \mathrm{kg}^{-1}\right)$ & 1.2 \\
\hline
\end{tabular}


Table.2 Nitrogen balance sheet (Kg/ha) after Kharif 2013

\begin{tabular}{|l|c|c|c|c|}
\hline Treatments & Applied & Removed & Balance & Change \\
\hline Control & 0 & 899 & -899 & -69 \\
\hline $50 \%$ NPK & 1450 & 1530 & -80 & -47 \\
\hline $100 \%$ NPK & 2900 & 2176 & 724 & -19 \\
\hline $150 \%$ NPK & 4350 & 2657 & 1693 & 5 \\
\hline $100 \%$ NPK+Zn & 2900 & 2166 & 734 & -34 \\
\hline $100 \%$ NP & 2900 & 2133 & 767 & -33 \\
\hline $100 \%$ N & 2900 & 1614 & 1286 & -28 \\
\hline $100 \%$ NPK+FYM & 3263 & 2411 & 852 & 5 \\
\hline $50 \%$ NPK+BGA & 1450 & 1627 & -177 & -50 \\
\hline $50 \%$ NPK+ GM & 1857 & 1911 & -54 & -18 \\
\hline
\end{tabular}

Table.3 Phosphorus balance sheet (Kg/ha) after Kharif 2013

\begin{tabular}{|l|c|c|c|c|}
\hline Treatments & Applied & Removed & Balance & Change \\
\hline Control & 0 & 140 & -140 & -7.1 \\
\hline $50 \%$ NPK & 380 & 248 & 132 & 4.8 \\
\hline $100 \%$ NPK & 760 & 342 & 418 & 13 \\
\hline $150 \%$ NPK & 1140 & 411 & 729 & 15.4 \\
\hline $100 \%$ NPK+Zn & 760 & 354 & 406 & 12.9 \\
\hline $100 \%$ NP & 760 & 338 & 421 & 12.1 \\
\hline $100 \%$ N & 0 & 202 & -202 & -7.7 \\
\hline $100 \%$ NPK+FYM & 1035 & 401 & 634 & 14.1 \\
\hline $50 \%$ NPK+BGA & 380 & 258 & 122 & 3.1 \\
\hline $50 \%$ NPK+ GM & 380 & 286 & 94 & 5.2 \\
\hline
\end{tabular}

Table.4 Potassium balance sheet (Kg/ha) after Kharif 2013

\begin{tabular}{|l|c|c|c|c|}
\hline Treatments & Applied & Removed & Balance & Change \\
\hline Control & 0 & 1593 & -1593 & -113 \\
\hline $50 \%$ NPK & 538 & 2748 & -2210 & -93 \\
\hline $100 \%$ NPK & 1077 & 3682 & -2605 & -82 \\
\hline $150 \%$ NPK & 1615 & 4383 & -2769 & -62 \\
\hline $100 \%$ NPK+Zn & 1077 & 3774 & -2697 & -86 \\
\hline $100 \%$ NP & 0 & 3523 & -3524 & -101 \\
\hline $100 \%$ N & 0 & 2791 & -2791 & -115 \\
\hline $100 \%$ NPK+FYM & 1663 & 3976 & -2312 & -61 \\
\hline $50 \%$ NPK+BGA & 538 & 2808 & -2270 & -88 \\
\hline $50 \%$ NPK+ GM & 538 & 3432 & -2894 & -92 \\
\hline
\end{tabular}


Table.5 Effect of long term fertilizer and manures on bulk density, OC, SOC stock and carbon sequestration rate

\begin{tabular}{|l|c|c|c|c|}
\hline Treatments & $\begin{array}{l}\text { Bulk } \\
\text { Density }\end{array}$ & O.C & SOC stock & Carbon Sequestration Rate \\
\hline Control & 1.43 & 0.44 & 9.43 & -3.302 \\
\hline $50 \%$ NPK & 1.37 & 0.58 & 11.91 & -0.821 \\
\hline $100 \%$ NPK & 1.37 & 0.63 & 12.94 & 0.206 \\
\hline $150 \%$ NPK & 1.39 & 0.65 & 13.55 & 0.812 \\
\hline $100 \%$ NPK+Zn & 1.42 & 0.55 & 11.71 & -1.025 \\
\hline $100 \%$ NP & 1.36 & 0.54 & 11.01 & -1.724 \\
\hline $100 \%$ N & 1.47 & 0.45 & 9.93 & -2.817 \\
\hline $100 \%$ NPK+FYM & 1.3 & 0.66 & 12.87 & -1.082 \\
\hline $50 \%$ NPK+BGA & 1.34 & 0.58 & 11.66 & -0.662 \\
\hline $50 \%$ NPK+ GM & 1.32 & 0.61 & 12.07 & \\
\hline
\end{tabular}

Fig.1 Effect of long-term fertilizer experiments on soil organic carbon stock

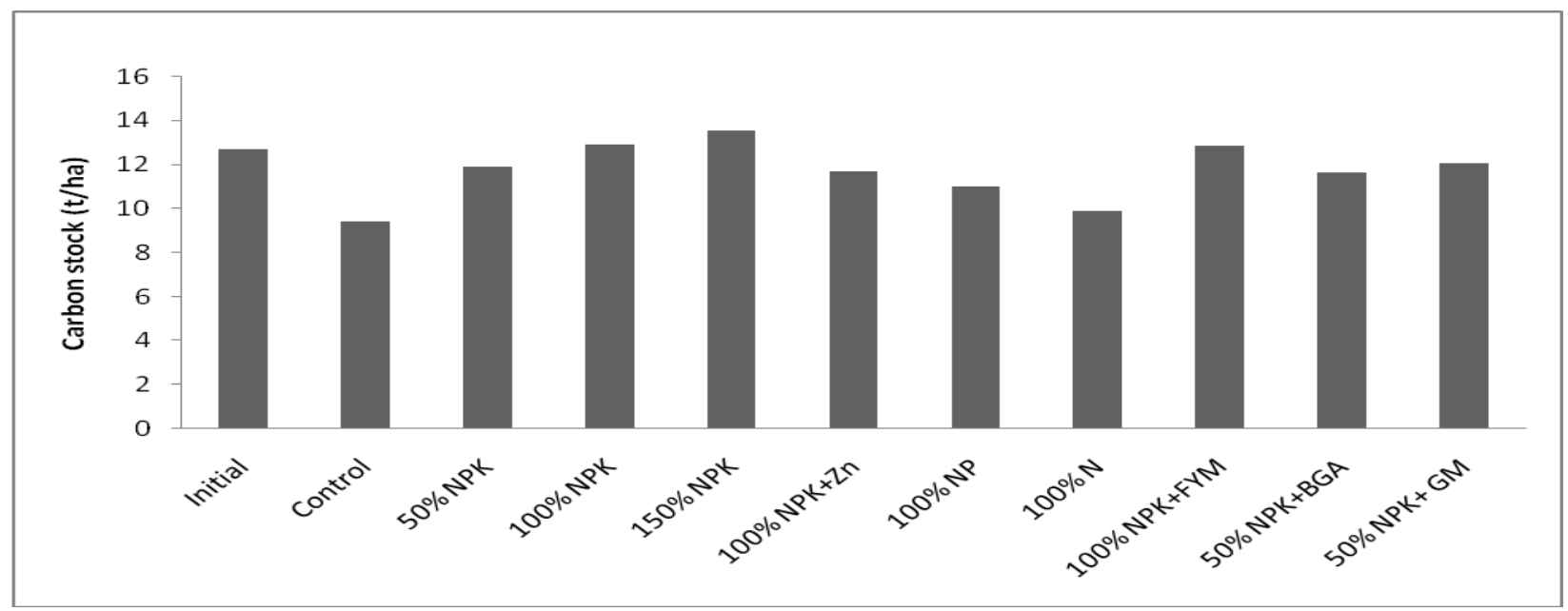

Fig.2 Effect of bulk density $\left(\mathrm{Mg} \mathrm{m}^{-3}\right)$ on soil organic carbon stock

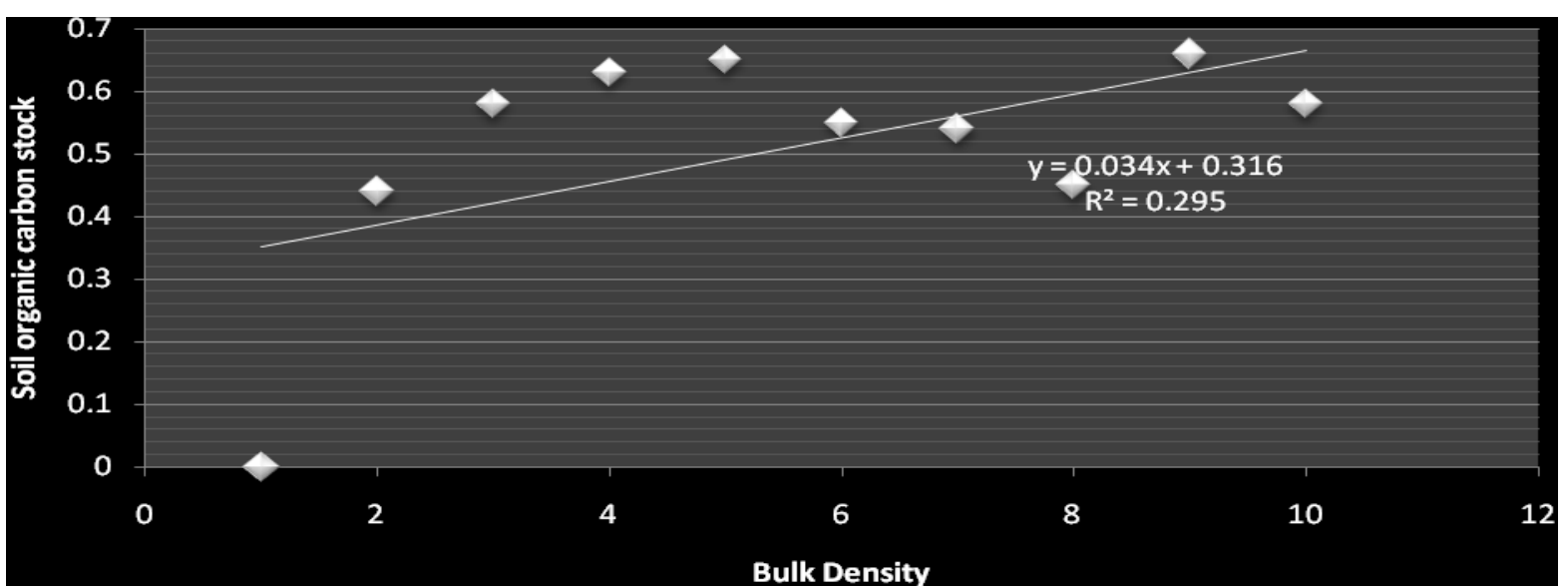


Fig.3 Effect of Integrated nutrient management treatments on grain and straw yield ( $\mathrm{Kg} / \mathrm{ha})$

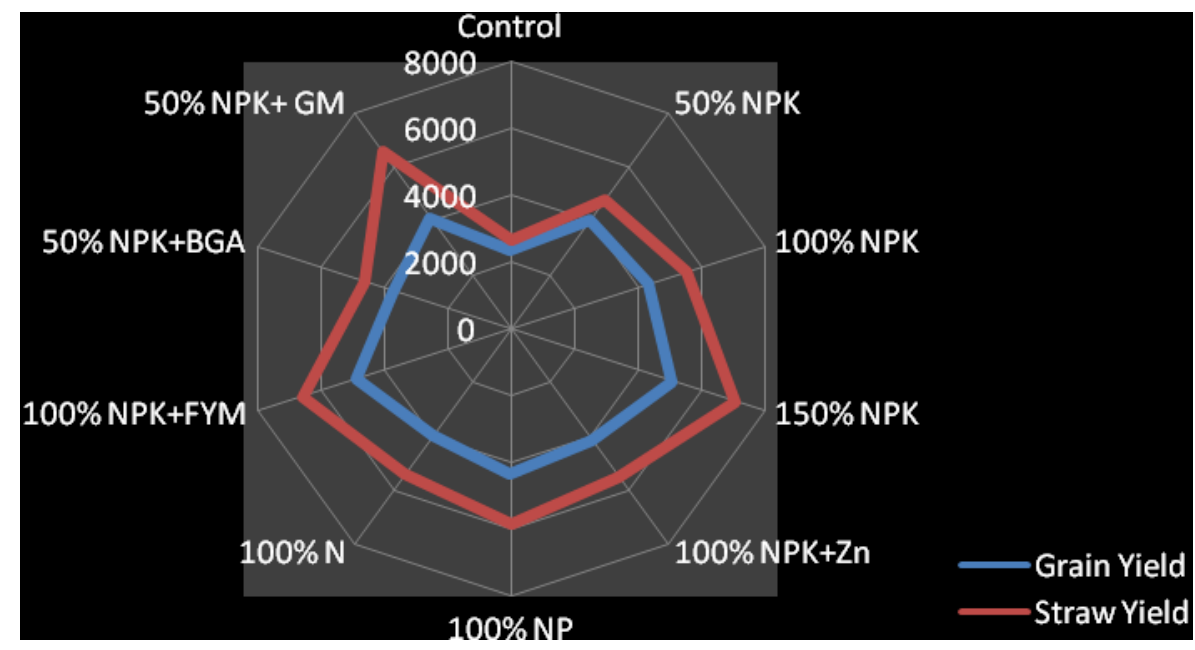

Increasing rates of fertilizer application increased phosphorus balance surplus. For the potassium balance a clear difference was evident between the treatments. The potassium balance was negative at all the levels of fertilization for the harvest of total production. The higher change in ' $\mathrm{K}$ ' balance was recorded in $100 \% \mathrm{NPK}+\mathrm{FYM}$ treatment followed by $150 \%$ NPK treatment and the lower values were recorded in $100 \% \mathrm{~N}$ treatment followed by Control (Table.4) Potassium balance was sensitive to the level of potassium application and to the uptake. When all the plant parts were removed potassium balance was always negative. The higher values obtained by different treatments due to high level of potassium application.

In conclusion, the prediction of future SOC sequestration potential demonstrated that under no fertilizer input, these soils would be a net source of $\mathrm{CO}_{2}$. Even when inorganic nutrients were applied, the additional carbon input from increased plant residues could not meet the depletion of SOC. Manure or straw application could improve the carbon sequestration, with straw being a more likely option into the future. The loss of soil fertility in many developing countries due to continuous nutrient depletion by crops without adequate replenishment poses an immediate threat to food and environmental securities. There is a need to revive the age old practice of application of organic manures to maintain soil fertility and also to supplement many essential plant nutrients for crop productivity.

\section{References}

Babbu Singh Brar, Jagdeep Singh, Gurbir Singh and Gurpreet Kaur. 2015. Effects of Long Term Application of Inorganic and Organic Fertilizers on Soil Organic Carbon and Physical Properties in Maize-Wheat Rotation. Agron., 5: 220-238.

Bhattacharyya, R., Chandra, S., Singh, R. Kundu, S., Srivastva, A. and Gupta, H. 2007. Long- term farmyard manure application effects on properties of a silty clay loam soil under irrigated wheat-soybean rotation. Soil Till. Res., 94: 386-396.

Gregorich, E., Drury, C., and Baldock, J.A. 2001. Changes in soil carbon under long-term maize in monoculture and legume-based rotation. Can. J. Soil Sci., 81: 21-31.

Haynes, R. and Naidu, R. 1998. Influence of 
lime, fertilizer and manure applications on soil organic matter content and soil physical conditions: A review. Nutr. Cycl. Agroecosys., 51: 123-137.

Jarecki, M.K. and Lal, R. 2003. Crop management for soil carbon sequestration. Crit. Rev. Plant Sci., 22: 471-502.

Lal, R. 2003. Soil erosion and the global carbon budget. Environ. Int., 29: 437450.

Lal, R. 2004. Soil carbon sequestration impacts on global climate change and food security. Sci., 304: 1623-1627.

McLauchlan, K.K. 2006. Effects of soil texture on soil carbon and nitrogen dynamics after cessation of agriculture, Geoderma, 136: 289-299.

Zhang, S., Yang, X,; Wiss, M., Grip, H. and Lövdahl, L. 2006. Changes in physical properties of a loesssoil in china following two long-term fertilization regimes. Geoderma, 136: 579-587.

\section{How to cite this article:}

Challa Venu Reddy, Laxmi Kashyap and Alok Tiwari. 2017. Effect of 14-Year Long Term Fertilizer Management on Soil Organic Carbon Stock, Carbon Sequestration Rate and Nutrient Balances in Vertisols. Int.J.Curr.Microbiol.App.Sci. 6(7): 895-902. doi: https://doi.org/10.20546/ijcmas.2017.607.110 